\title{
Analisis Kemampuan Pemahaman Matematis SisWa SMP Pada MATERI BENTUK ALJABAR
}

\author{
Ai Mulyani' ${ }^{1}$ Eneng Kurnia Nur Indah ${ }^{2}$ dan Angga Permana Satria ${ }^{3}$ \\ 1Pendidikan Matematika, IKIP Siliwangi \\ Jl. Terusan Jenderal Sudirman, Cimahi, Indonesia \\ mulyaniai994@gmail.com \\ ${ }^{2}$ Pendidikan Matematika, IKIP Siliwangi \\ Jl. Terusan Jenderal Sudirman, Cimahi, Indonesia \\ kurnia083826038584@gmail.com \\ ${ }^{3}$ Pendidikan Matematika, IKIP Siliwangi \\ Jl. Terusan Jenderal Sudirman, Cimahi, Indonesia \\ anggasatria217@gmail.com
}

\begin{abstract}
Abstrak
Kemampuan pemahaman matematis dapat mencapai tujuan pembelajarannya apabila mereka dapat memahami konsep dengan baik. Penelitian ini bertujuan untuk mengetahui kemampuan pemahaman matematis siswa SMP di Kabupaten Bandung Barat pada materi bentuk aljabar. Metode yang digunakan dalam penelitian ini adalah metode deskriptif dengan menggunakan pendekatan kualitatif. Subjek terdiri dari 35 siswa. Data yang dikumpulkan berupa hasil tes kemampuan pemahaman matematis, hasil angket siswa, dan dokumentasi. Berdasarkan hasil analisis data, bahwa kemampuan pemahaman matematis siswa SMP Kabupaten Bandung Barat masih rendah. Hal ini terbukti bahwa siswa tidak dapat menerapkan rumus dalam perhitungan sederhana dan mengerjakan perhitungan secara algoritmik, mengaitkan satu konsep dengan konsep lainnya dan mampu menerapkan konsep yang telah dipelajari sebelumnya dengan konsep yang terdapat pada bentuk aljabar, sehingga siswa kesulitan dalam menyelesaikan soal. Siswa mengalami kesulitan dalam memahami soal, tidak tertantang menyelesaikan soal matematika yang tidak rutin, gugup dalam menjawab pertanyaan tentang materi matematika yang kurang dipahami, ragu-ragu dapat mempelajari sendiri materi matematika yang sulit, tidak dapat menemukan cara baru ketika sulit mengerjakan soal matematika dan menghindari memilih soal latihan matematika yang sulit.

Kata Kunci: Kemampuan Pemahaman, Bentuk Aljabar, Pendapat Siswa
\end{abstract}

\begin{abstract}
The ability of mathematical understanding can achieve their learning objectives if they can understand the concept well. This research is aimed to know mathematical comprehension ability of junior high school student in Kabupaten Bandung Barat on the material of algebra. The method used in this research is descriptive method by using qualitative approach. The students consist of 35 students. Data collected in the form of result test of mathematical comprehension ability, student questionnaire result and documentations. Based on data analysis that the ability of junior high school student mathematical comprehension is still low, it is proven that student cannot apply the formula in simple calculation and carry out calculation algorithmically, connecting one concept to another concept in algebra. So, student gets difficulty in doing the cases. Student gets difficulty in understanding question, have no challenge in doing mathematic cases rarely given, be nervous in answering question about mathematic material that is poorly understood, be hesitance in learning for themselves difficulty mathematic material, cannot find a new method while getting difficult to do mathematic question and avoiding to choose the difficult mathematic exercise.

Keyword: Ability of Understanding, Algebraic Form, Student's Opinion
\end{abstract}


http://journal.institutpendidikan.ac.id/index.php/mosharafa

\section{Pendahuluan}

Pemahaman matematis diterjemahkan dari istilah mathematical understanding merupakan kemampuan matematis yang sangat penting dan harus dimiliki siswa dalam belajar matematika. Rasional pentingnya pemilikan kemampuan pemahaman matematis di antaranya adalah kemampuan tersebut tercantum dalam tujuan pembelajaran matematika Kurikulum Matematika SM (KTSP 2006 dan Kurikulum 2013) dan dalam NCTM (1989). Pernyataan tersebut sesuai dengan pendapat Hudoyo (Hendriana, dkk. 2017:3) yang menyatakan: "Tujuan mengajar matematika adalah agar pengetahuan yang disampaikan dapat dipahami peserta didik". Pendidikan yang baik adalah usaha yang berhasil membawa siswa kepada tujuan yang ingin dicapai yaitu agar bahan yang disampaikan dipahami sepenuhnya oleh siswa.

Pentingnya pemilikan pemahaman oleh siswa juga dikemukakan Santrock (Hendriana, dkk. 2017:3) bahwa pemahaman konsep adalah aspek kunci dari pembelajaran. Demikian pula, pemahaman matematis merupakan landasan penting untuk berpikir dalam menyelesaikan persoalan-persoalan matematika maupun masalah kehidupan nyata. Selain itu, kemampuan pemahaman matematis sangat mendukung pada pengembangan kemampuan matematis lainnya, yaitu komunikasi, pemecahan masalah, penalaran, koneksi, representasi, berpikir kritis dan berpikir kreatif matematis serta kemampuan matematis lainnya. Pendapat serupa dikemukakan Wiharno (Hendriana, dkk. 2017:4) bahwa kemampuan pemahaman matematis merupakan suatu kekuatan yang harus diperhatikan selama proses pembelajaran matematika, terutama untuk memperoleh pengetahuan matematika yang bermakna.

Qohar (Muna dan Afriansyah 2016) menyatakan bahwa kemampuan pemahaman matematis adalah kemampuan mengklasifikasikan obyekobyek matematika, menginterpretasikan gagasan atau konsep, menemukan contoh dari sebuah konsep, memberikan contoh dan bukan contoh dari sebuah konsep dan menyatakan kembali konsep matematika dengan bahasa sendiri.

Menunjuk pada pendapat beberapa pakar, Sumarmo (Hendriana, dkk. 2017:4) mengemukakan jenis dan tingkat pemahaman matematis sebagai berikut. Mengatakan ada empat tingkat pemahaman yaitu pemahaman mekanikal, pemahaman induktif, pemahaman rasional, dan pemahaman intuitif. Seseorang dikatakan mempunyai pemahaman mekanikal jika ia dapat mengingat dan menerapkan suatu konsep secara benar. Seseorang dapat dikatakan mempunyai pemahaman induktif jika ia menunjukkan konsep itu berlaku dalam kasus yang sederhana dan yakin bahwa konsep itu berlaku dalam kasus serupa. Seseorang dikatakan mempunyai pemahaman rasional jika ia dapat membuktikan kebenarannya. Kemudian seseorang dapat dikatakan mempunyai pemahaman intuitif jika ia yakin akan kebenaran konsep tersebut tanpa ada keraguan.

Siswa dapat memahami materi dengan baik apabila mencoba mempelajari terlebih dahulu. Putra \&Purwasih (2015) menyatakan bahwa belajar sebelum diajarkan dapat meningkatkan pemahaman terhadap materi yang akan dipelajari. Meskipun ketika mempelajari masih ada materi yang belum dipahami, namun di kelas siswa dapat bertanya pada guru 
ketika menjelaskan materi tersebut, sehingga tingkat pemahaman siswa terhadap materi menjadi lebih baik.Putra (2016) berpendapat siswa jangan dibatasi dari satu buku sumber saja dalam mempelajari materi.Siswa juga diarahkan menemukan konsep dari sumber atau media lain di internet agar pemahaman mereka terhadap konsep menjadi berkembang.

O'Connell (Nuraeni dan Luritawaty 2017) menyatakan bahwa dengan pemahaman matematis, siswa akan lebih mudah dalam memecahkan permasalahan karena siswa akan mampu mengaitkan serta memecahkan permasalahan tersebut dengan berbekal konsep yang sudah dipahaminya.

Berdasarkan beberapa penelitian mengemukakan bahwa kemampuan pemahaman matematis siswaSMP masih perlu ditingkatkan. Siswa masih mengalami kesulitan dalam memahami materi karena konsep matematika yang abstrak.

Berdasarkan hasil temuan Putra (2014) pada siswa di salah satu sekolah menengah pertama diperoleh bahwa dalam satu kelas yang terdiri dari 35 siswa, hanya 5 siswa yang sudah berada pada tahap berpikir formal (abstrak), sedangkan 30 siswa berada pada tahap berpikir operasi konkret, sehingga mereka kesulitan memahami konsep matematika yang masih abstrak bagi mereka.

Menurut penelitian Chotimah (2014) ditemukan bahwa pemahaman matematik siswa SMP masih rendah. Serupa dengan temuan Putra, dkk (2018) pada salah satu SMP sebanyak 41,67\% siswa masih memiliki kemampuan pemahaman pada kriteria rendah, sebesar 30,56\% berada pada kriteria sedang, dan $27,72 \%$ berada pada kriteria tinggi.
Berdasarkan pemaparan tentang kemampuan pemahaman matematis tersebut menunjukkan bahwa kemampuan pemahaman merupakan kemampuan yang penting untuk dikembangkan pada siswa sekolah menengah.

\section{Metode}

Penelitian ini merupakan penelitian deskriptif dengan menggunakan pendekatan kualitatif. Sukmadinata (Wahyuni dan Karimah 2017) menjelaskan bahwa peneltitian desktiptif adalah suatu penelitian yang ditujukan untuk mendeskripsikan fenomena-fenomena yang ada. Moleong (Wahyuni dan Karimah 2017) mengatakan bahwa penelitian kualitatif adalah penelitian yang menghasilkan data deskriptif berupa katakata tertulis, lisan dan perilaku dari orangorang yang diamati.

Penelitian dilakukan di SMPS Bandung Barat semester ganjil tahun ajaran 2017/2018. Subjek penelitian adalah siswa kelas VIII sebanyak satu kelas terdiri dari tiga puluh lima siswa. Metode pengumpulan data meliputi: (1) tes kemampuan pemahaman matematis; (2) angket; (3) dokumentasi. Penelitian ini dilaksanakan pada bulan November 2017.

Teknik pengumpulan data yang digunakan dalam penelitian ini yaitu melakukan kegiatan pendahuluan, mengkonsultasikan soal tes kemampuan pemahaman matematis dengan pembimbing yang berbentuk essay yang telah diuji validitas, daya pembeda dan indeks kesukarannya, mengumpulkan data, menganalsis data, dan menarik kesimpulan. 
Adapun kegiatan pendahuluan yang dilakukan yaitu menentukan lokasi penelitian, meminta ijin dari pihak sekolah, menyampaikan maksud dan tujuan penelitian kepada guru mata pelajaran matematika, dan menentukan subyek penelitian. Data yang dikumpulkan berupa hasil tes kemampuan pemahaman matematis dan angket sebanyak 35 siswa.

Instrument utama adalah peneliti. Peneliti merupakan perencana, pelaksanaan pengumpulan data, analis, penafsir data dan menjadi pelapor hasil penelitiannya. Instrument pendukung pada penelitian ini berupa tes dan angket. Tes yang digunakan pada penelitian ini adalah tes kemampuan pemahaman matematis yang terdiri dari 4 soal berupa soal-soal bentuk aljabar dan angket siswa kemampuan diri (self-efficacy) sebanyak 28 butir.

Pada masing-masing soal siswa diminta untuk menyelesaikan permasalahan yang diminta dan mengisi angket sesuai dengan kemampuan dirinya. Tes dan angket yang digunakan telah dikonsultasikan kepada pembimbing. Selain itu, rubrik penilaian tes disusun berdasarkan indikator pemahaman matematis yang telah ditentukan.

\section{Hasil dan Pembahasan}

Langkah pertama yang dilakukan dalam pelaksanaan penelitian yaitu menentukan materi, menyusun tes kemampuan pemahaman dan angket. Soal tes yang digunakan yaitu yang sudah diuji validitas, daya pembeda dan indeks kesukarannya selanjutnya tes tersebut dikonsultasikan dengan pembimbing. Setelah itu, meminta izin kepada pihak sekolah untuk melakukan penelitian dan menentukan subjek penelitian. Kemudian dilakukan tes kepada satu kelas sebanyak 35 siswa yang sudah ditentukan. Tes dilakukan selama 60 menit. Selanjutnya data diolah dan dianalisis berdasarakan rubrik penilaian. Adapun soal nomor 1 yang diadobsi dari Rukoyah (2017) yaitu:

\section{Tentukanlah nilai dari:}

$$
\begin{aligned}
& \text { a. }\left(x^{2}+x-6\right)-2 x(2-x) \\
& \text { b. } \frac{x^{2}+-6}{x+3}
\end{aligned}
$$

Gambar 1. Soal nomor 1 bagian a.

Pada soal nomor 1 bagian a, siswa diminta menentukan nilai dari bentuk aljabar dengan menerapkan rumus dalam perhitungan sederhana dan mengerjakan perhitungan secara algoritmik. Berdasarkan hasil analisis, diketahui 35 siswa atau 100\% yang memperoleh skor 2 . Berikut ini contoh hasil pekerjaan siswa yang mengalami kesalahan dalam menyelesaikan soal.

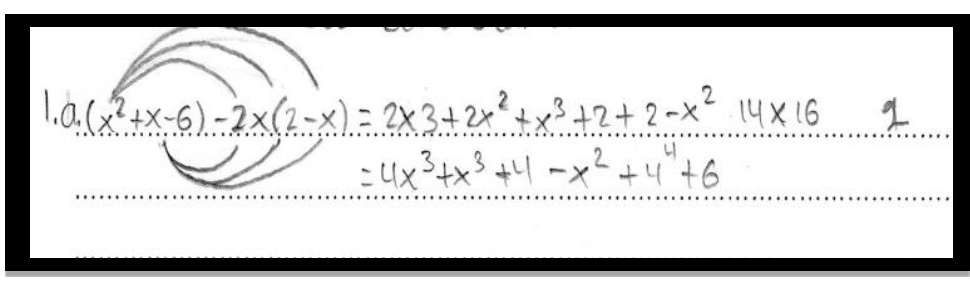

Gambar 2. Jawaban siswa untuk nomor 1 bagian a 
Soal nomor 1 bagian $b$, siswa diminta untuk menentukan nilai dari bentuk aljabar dengan menerapkan rumus dalam perhitungan sederhana dan mengerjakan perhitungan secara algoritmik. Berdasarkan hasil analisis, diketahui 32 siswa atau 91,42\% yang memperoleh skor 2, 2 siswa atau 5,71\% yang memperoleh skor 4 dan 1 siswa atau 2,85\% yang memperoleh skor 0. Berikut ini contoh hasil pekerjaan siswa yang mengalami kesalahan dalam menyelesaikan soal.

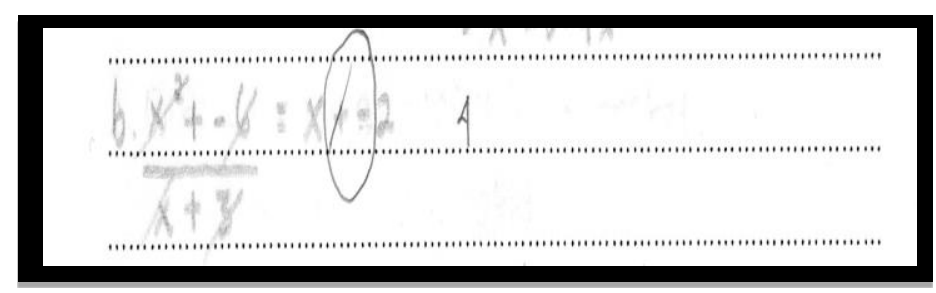

Gambar 3. Jawaban siswa untuk nomor 2 bagian $b$

Pada soal nomor 2, siswa diminta untuk perhitungan secara algoritmik. Berikut menentukan nilai dari bentuk aljabar tampilan soal nomor 2 yang diadobsi dari dengan menerapkan rumus dalam Rukoyah (2017).

perhitungan sederhana dan mengerjakan

2. Anton mempunyai empat buah tongkat. Panjang dua tongkat $(5+\mathrm{x}) \mathrm{cm}$ dan panjang dua tongkat lainnya $(\mathrm{x}-1) \mathrm{cm}$. Anton menyusun keempat tongkat tersebut dengan du acara, yaitu:

a. Disusun menjadi tongkat panjang

Nyatakan panjang tongkat panjang tersebut dalam bentuk aljabar

b. Disusun kembali kerangka persegi panjang

Nyatakan luas daerah persegi panjang yang terbentuk dalam bentuk aljabar

Gambar 4. Soal nomor 2

Pada soal nomor 2, Berdasarkan hasil analisis, diketahui 31 siswa atau 88,57\% yang memperoleh skor 2 , dan 4 siswa atau $11,42 \%$ yang memperoleh skor 1 . Berikut ini contoh hasil pekerjaan siswa yang mengalami kesalahan dalam menyelesaikan soal. 


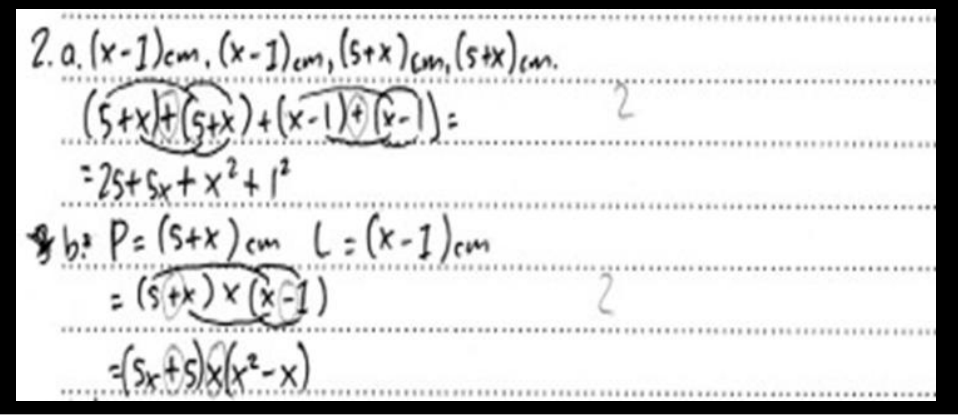

Gambar 5. Jawaban siswa untuk soal nomor 2

Pada soal nomor 3, siswa diminta untuk lainnya. Berikut tampilan soal nomor 3 yang mengaitkan konsep dengan konsep diadobsidari Rukoyah (2017).

\section{Perhatikan gambar di bawah ini.}

(i)

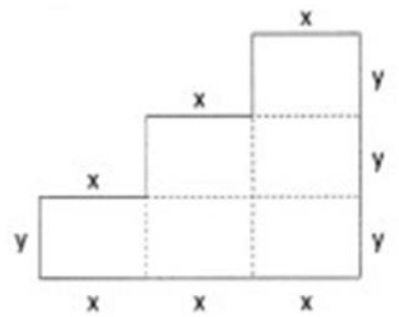

(ii)

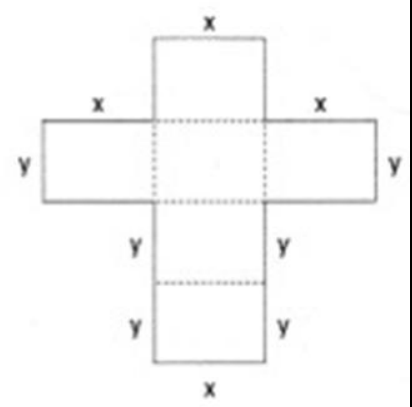

Bangun manakah yang kelilingnya lebih panjang? Jelaskan jawabanmu!

Gambar 6. Soal nomor 3

Pada soal nomor 3, semua siswa hanya menentukan kelilingnya dengan gambarnya saja tanpa menjelaskan cara mencari kelilingnya. Berdasarkan hasil analisis terhadap tes, diketahui semua siswa 35 atau 100\% siswa yang mendapat skor 2. Berikut ini contoh hasil pekerjaan siswa yang hanya menentukan jawaban tanpa uraian penjelasannya.

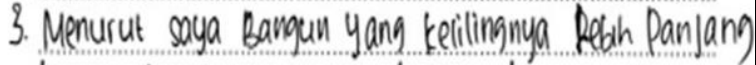
bamun yang hober 11 karera bampan yg NO 1 xelle Lebin Pender dari Pada ys 102 2

Gambar 7. Jawaban siswa untuk soal nomor 3

Pada soal nomor 4, siswa diminta untuk mengaitkan konsep dengan konsep
lainnya.Berikut tampilan soal nomor 4yang diadobsi dariRukoyah (2017). 
4. Vio dan Bela masing-masing memiliki sehelai karton. Karton vio berbentuk persegi dengan panjang sisinya $(x+2) \mathrm{cm}$ dan karton Bela berbentuk persegi panjang dengan ukuran panjang $(x+8) \mathrm{cm}$ sedangkan lebarnya $(x-2) \mathrm{cm}$. bila luas karton mereka sama, maka karton siapakah yang kelilingya lebih panjang? Jelaskan jawabanmu!

Gambar 8. Soal nomor 4

Pada soal nomor 4, semua siswa hanya menyimpulkan jawaban tanpa menjelaskan jawabannya. Berdasarkan hasil analisis terhadap tes, diketahui semua siswa 35 atau 100\% siswa yang mendapat skor 1 . Berikut ini contoh hasil pekerjaan siswa yang hanya menyimpulkan jawaban.

\section{4 kapzon bela karena karton bela kelilimang leblh Pangung dari karton Vio}

Gambar 9. Jawaban untuk soal nomor 4

Berdasarkan hasil analisis terhadap hasil tes, diketahui bahwa hampir semua siswa belum mampu mengerjakan soal nomor satu sampai empat. Hal ini dilihat dari 35 siswa pada soal nomor satu bagian a 35 siswa atau $100 \%$ yang memperoleh skor 2 , nomor satu bagian b diketahui 32 siswa atau 91,42\% yang memperoleh skor 2, 2 siswa atau 5,71\% yang memperoleh skor 4 dan 1 siswa atau 2,85\% yang memperoleh skor 0 , soal nomor 2 diketahui 31 siswa atau $88,57 \%$ yang memperoleh skor 2 , dan 4 siswa atau 11,42\% yang memperoleh skor1, soal nomor 3 diketahui semua siswa 35 atau $100 \%$ siswa yang mendapat skor 2 , dan soal nomor 4 diketahui semua siswa 35 atau $100 \%$ siswa yang mendapat skor 1 .
Selain berdasarkan hasil tes, peneliti memberikan angket kepada satu kelas tersebut dengan jumlah siswa yang sama 35 siswa yang menjadi subjek penelitian, banyaknya item soal positif ada 14 item dan banyaknya item soal negatif ada 14 item total item 28, masing-masing jawaban dikaitkan dengan nilai, misal SS $=4, S=3$, TS $=2$, dan STS $=1$ bagi pertanyaan yang mendukung sikap positif dan nilai-nilai sebaliknya $\mathrm{SS}=1, \mathrm{~S}=2, \mathrm{TS}=3$, dan $\mathrm{STS}=4$ bagi pernyataan yang mendukung sikap negatif. Berikut persentase hasil angket pada Tabel 1. 
Tabel 1.

Hasil Presentase Angket

\begin{tabular}{|c|c|c|c|c|c|c|c|c|c|c|c|c|c|c|}
\hline \multirow{2}{*}{ ANGKA/NILAI } & \multicolumn{7}{|c|}{ NO ITEM SOAL (\%) } & \multicolumn{7}{|c|}{ NO ITEM SOAL (\%) } \\
\hline & 1 & 2 & 3 & 4 & 5 & 6 & 7 & 8 & 9 & 10 & 11 & 12 & 13 & 14 \\
\hline 1 & 23 & 11 & 11 & 6 & 0 & 14 & 11 & 3 & 14 & 6 & 9 & 3 & 3 & 9 \\
\hline 2 & 54 & 29 & 31 & 17 & 11 & 51 & 51 & 43 & 26 & 29 & 3 & 29 & 9 & 51 \\
\hline 3 & 20 & 46 & 29 & 49 & 23 & 34 & 31 & 43 & 20 & 57 & 54 & 49 & 43 & 26 \\
\hline 4 & 3 & 14 & 29 & 29 & 66 & 0 & 6 & 11 & 40 & 9 & 34 & 20 & 46 & 14 \\
\hline
\end{tabular}

\begin{tabular}{|c|c|c|c|c|c|c|c|c|c|c|c|c|c|c|}
\hline \multirow{2}{*}{ ANGKA/NILAI } & \multicolumn{7}{|c|}{ NO ITEM SOAL (\%) } & \multicolumn{7}{|c|}{ NO ITEM SOAL (\%) } \\
\hline & 15 & 16 & 17 & 18 & 19 & 20 & 21 & 22 & 23 & 24 & 25 & 26 & 27 & 28 \\
\hline 1 & 6 & 0 & 11 & 3 & 9 & 9 & 9 & 6 & 0 & 11 & 11 & 0 & 17 & 9 \\
\hline 2 & 34 & 0 & 31 & 14 & 40 & 20 & 31 & 14 & 34 & 37 & 23 & 3 & 11 & 31 \\
\hline 3 & 40 & 57 & 54 & 57 & 43 & 29 & 57 & 46 & 46 & 43 & 46 & 49 & 43 & 43 \\
\hline 4 & 20 & 43 & 3 & 26 & 9 & 43 & 3 & 34 & 20 & 9 & 20 & 49 & 29 & 17 \\
\hline
\end{tabular}

Berdasarkan Tabel 1 presentase hasil angket pada item pertanyataan pertama saya gugup menjawab peryantaan tentang materi matematika yang kurang dipahami 23\% siswa menyatakan sangat setuju, 54\% setuju, 20\% tidak setuju, 3\% sangat tidak setuju, pernyataan ke dua saya dapat segera menemukan cara baru ketika macet mengerjakan soal matematika 11\% siswa menyatakan sangat setuju, 29\% setuju, 46\% tidak setuju, 14\% sangat tidak setuju, pernyataan ke tiga saya menunggu bantuan teman ketika kesulitan menyelesaikan soal matematika $11 \%$ siswa menyatakan sangat setuju, 31\% setuju, 29\% tidak setuju, 29\% sangat tidak setuju, pertanyaan ke empat saya mampu mengatasi kesulitan belajar matematika sendiri $6 \%$ siswa menyatakan sangat setuju, $17 \%$ setuju, $49 \%$ tidak setuju, 29\% sangat tidak setuju.

Pernyataan ke lima saya yakin akan berhasil dalam ulangan matematika yang akan datang $0 \%$ siswa menyatakan sangat setuju, 11\% setuju, 23\% tidak setuju, 66\% sangat tidak setuju, pernyataan ke enam saya ragu-ragu dapat mempelajari sendiri materi matematika yangg sulit $14 \%$ siswa menyatakan sangat setuju, 51\% setuju, 34\% tidak setuju, 0\% sangat tidak setuju, peryataan ke tujuh saya kuatir gagal menyelesaikan tugas matematika yang berat $11 \%$ siswa menyatakan sangat setuju, 51\% setuju, 31\% tidak setuju, 6\% sangat tidak setuju, pernyataan ke delapan saya mengelak memilih soal latihan matematika yang sulit 3\% siswa menyatakan sangat setuju, 43\% setuju, 43\% tidak setuju, 11\% sangat tidak setuju.

Pernyataan ke sembilan berdiskusi dengan teman yang pandai matematika adalah menyenangkan $14 \%$ siswa menyatakan sangat setuju, $26 \%$ setuju, $20 \%$ tidak setuju, 40\% sangat tidak setuju, pernyataan ke sepuluh mempelajari tugas matematika yang baru adalah mencemaskan 6\% siswa menyatakan sangat setuju, 29\% setuju, 57\% tidak setuju, 9\% sangat tidak setuju, pernyataan ke sebelas saya berani menghadapi kritikan atas tugas matematika yang saya kerjakan 9\% siswa meneyatakan sangat setuju, 3\% setuju, 54\% tidak setuju, 34\% sangat tidak setuju, pernyataan ke dua belas saya 
menghindar mencoba cara yang berbeda dengan contoh dari guru $3 \%$ siswa menyatakan sangat setuju, 29\% setuju, 49\% tidak setuju, 20\% sangat tidak setuju.

Pernyataan ke tiga belas saya berani mencoba cara baru meski risiko gagal 3\% siswa menyatakan sangat setuju, $9 \%$ setuju, $43 \%$ tidak setuju, 46\% sangat tidak setuju, pertanyataan ke empat belas saya bersedia ditunjuk sebagai ketua kelompok matematika 9\% siswa menyatakan sangat setuju, 51\% setuju, 26\% tidak setuju, 14\% sangat tidak setuju, pernyataan ke lima belas saya takut mengikuti seleksi siswa berprestasi matematika antar sekolah 6\% siswa menytakan sangat setuju, 34\% setuju, 40\% tidak setuju, 20\% sangat tidak setuju, pernyataan ke enam belas saya menyadari kesalahan yang terjadi dalam ulangan matematika yang lalu 0\% siswa menyatakan sangat setuju, $0 \%$ setuju, $57 \%$ tidak setuju, 43\% sangat tidak setuju.

Pernyataan ke tujuh belas saya bingung memilih materi matematika yang akan ditanyakan kepada guru $11 \%$ siswa menyatakan sangat setuju, $31 \%$ setuju, 54\% tidak setuju, 3\% sangat tidak setuju, pernyataan ke delapan belas saya tahu materi matematika yang perlu dipelajari ulang 3\% siswa menyatakan sangat setuju, $14 \%$ setuju, $57 \%$ tidak setuju, 26\% sangat tidak setuju, pernyataan ke sembilan belas saya ragu-ragu berhasil menyelesaikan tugas matematika yang berat 9\% siswa menyatakan sangat setuju, $40 \%$ setuju, 43\% tidak setuju, 9\% sangat tidak setuju, pernyataan ke dua puluh saya yakin akan memperoleh nilai terbaik dalam ulangan matematika 9\% siswa menyatakan sangat setuju, 20\% setuju, 29\% tidak setuju, 43\% sangat tidak setuju.

Pernyataan ke dua puluh satu saya canggung belajar matematika dengan orang yang belum di kenal 9\% siswa menyatakan sangat setuju, $31 \%$ setuju, $57 \%$ tidak setuju, 3\% sangat tidak setuju, pernyataan ke dua puluh dua saya merasa nyaman berdiskusi matematika dengan siapapun 6\% siswa menyatakan sangat setuju, 14\% setuju, 46\% tidak setuju, 34\% sangat tidak setuju, pernyataan ke dua puluh tiga saya berani mengemukakan pendapat sendiri di forum diskusi matematika 0\% siswa menyatakan sangat setuju, 34\% setuju, 46\% tidak setuju, 20\% sangat tidak setuju, pernyataan ke dua puluh empat saya ragu dapat menyampaikan hasil diskusi dengan baik mewakili kelompok matematika 11\% siswa menyatakan sangat setuju, $37 \%$ setuju, 43\% tidak setuju, 9\% sangat tidak setuju.

Pernyataan ke dua puluh lima saya merasa lelah belajar matematika dalam waktu yang lama $11 \%$ siswa menyatakan sangat setuju, 23\% setuju, $46 \%$ tidak setuju, $20 \%$ sangat tidak setuju, pernyataan ke dua puluh enam saya mencoba memperbaiki pekerjaan matematika yang belum sempurna 0\% siswa menyatakan sangat setuju, 3\% setuju, 49\% tidak setuju, 49\% sangat tidak setuju, pernyataan ke dua puluh tujuh saya menyerah menghadapi tugas matematika yang berat $17 \%$ siswa menyatakan sangat setuju, $11 \%$ setuju, 43\% tidak setuju, 29\% sangat tidak setuju, dan pernyataan ke dua puluh delapan saya 
tertantang menyelesaikan soal matematika yang tidak rutin 9\% siswa menyatakan sangat setuju, 31\% setuju, 43\% tidak setuju, $17 \%$ sangat tidak setuju.

\section{Penutup}

Berdasarkan hasil analisis dan pembahasan dapat disimpulkan kemampuan pemahaman matematis siswa kelas VIII SMPS Kabupaten Bandung Barat dalam menyelesaikan soal bentuk aljabar masih rendah. Hal tersebut ditunjukkan dengan hasil tes awal kemampuan pemahaman matematis siswa tidak menerapkan rumus dalam perhitungan sederhana dan mengerjakan perhitungan secara algoritmik dan mengaitkan satu konsep dengan konsep lainnya. meskipun siswa belum memperoleh jawaban yang tepat, tetapi siswa telah berusaha untuk menerapkan rumus dalam perhitungan sederhana pada bentuk aljabar.

Untuk mengatasi rendahnya kemampuan pemahaman siswa sebaiknya peneliti dapat melakukan inovasi dalam pembelajaran matematika seperti menggunakan pendekatan atau model pembelajaran yang inovatif.

\section{Daftar Pustaka}

Chotimah, S. (2014). Upaya Meningkatkan Kemampuan Pemahaman Matematik Siswa dengan Pendekatan Realistic Mathematics Educations pada Siswa SMP di Kota Bandung. Prosiding Seminar Nasional Pendidikan Matematika. 2, (pp.133-139). Cimahi: STKIP Siliwangi.
Hendriana, H, Rohaeti E. E, \& Sumarmo, U. (2017). Hard Skills dan Soft Skills Matematika Siswa. Bandung: Refika Aditama.

Muna, D.N, \& Afriansyah, E.A. (2016). Peningkatan Kemampuan Pemahaman Matematis Siswa melalui Pembelajaran Kooperatif Teknik Kancing Gemerincing dan Number Head Together. Mosharafa: Jurnal Pendidikan Matematika, 5(2), 169176.

Nuraeni, R, \& Luritawaty, I. P. (2017). Perbandingan Kemampuan

Pemahaman Matematis Siswa antara yang Menggunakan Pembelajaran Inside-Outside-Circle dengan Konvensional. Mosharafa: Jurnal Pendidikan Matematika, 6(3), 441449.

Putra, H. D. (2014). Tahap Perkembangan Kognitif Matematika Siswa MTs Asy Syifa Kelas IX Berdasarkan Teori Piaget. Prosiding Seminar Nasional Pendidikan Matematika. 2, (pp. 224-230). Cimahi: STKIP Siliwangi.

Putra, H. D, \& Purwasih, R. (2015). Meningkatkan Prestasi Belajar dan Keaktifan Mahasiswa Melalui Project Based Learning. Jurnal IImiah UPT P2M STKIP Siliwangi, 2(2), 128-136.

Putra, H. D. (2016). Pengaruh Project Based Learning Terhadap Kemadirian Belajar Mahasiswa. Prosiding Seminar Pendidikan Nusantara 2016 (pp.106115). Cimahi: STKIP Siliwangi.

Putra, H. D. (2018). Kemampuan Pemahaman Matematis Siswa SMP di Bandung Barat. Jurnal Penelitian dan Pembelajaran Matematika. 11(1): 28.

Rukoyah, S. (2017). Meningkatkan Kemampuan Pemahaman dan Pemecahan Masalah Matematik serta Kemandiriam Belajar Siswa SMP 
dengan Menggunakan Pendekatan Metakognitif. Tesis pada Pascasarjana STKIP Siliwangi, Bandung: tidak dipublikasikan.

Wahyuni \& Karimah. (2017). Analisis Kemampuan Pemahaman dan Penalaran Matematis Mahasiswa Tingkat IV Materi Sistem Bilangan Kompleks pada Mata Kuliah Analisis Kompleks. Jurnal Nasional Pendidikan Matematika, 1(2): 232-233.

\section{Riwayat Hidup PenUlis}

\section{Ai Mulyani, S.Pd.}

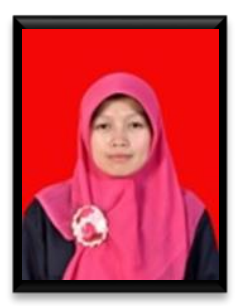

Lahir di Bandung, 17 Juli 1994. Staf Tata Usaha di SMK Budi Bakti Utama. Mahasiswa IKIP Siliwangi Bandung Jurusan Pendidikan Matematika.

\section{Eneng Kurnia Nur Indah, S.Pd.}

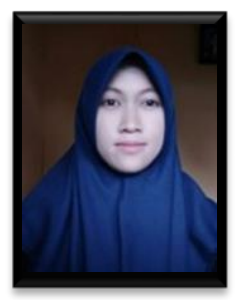

Lahir di Bandung, 27 Mei 1992. Staf Pengajar di MTs Darunadwah. Mahasiswa IKIP Siliwangi Bandung Jurusan Pendidikan Matematika.

\section{Angga Permana Satria, S.Pd.}

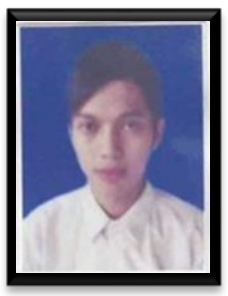

Lahir di Cimahi, 07 April 1992. Staf Pengajar di SMK Wyata Mandala Cipatat Mahasiswa IKIP Siliwangi Bandung Jurusan Pendidikan Matematika. 
This page is intentionally left blank 